\title{
Phytomining for Artisanal Gold Mine Tailings Management
}

\author{
Baiq Dewi Krisnayanti ${ }^{1}$, Christopher W.N. Anderson ${ }^{2, *}$, S. Sukartono ${ }^{1}$, Yusrin Afandi ${ }^{1}$, \\ Herman Suheri ${ }^{1}$ and Ardiana Ekawanti ${ }^{3}$ \\ 1 Agriculture Faculty, University of Mataram, Jl. Pendidikan No. 37, Mataram 83127, Indonesia; \\ bdewi.krisnayanti@gmail.com (B.D.K.); sukartonosukartono@yahoo.com (S.S.); \\ yusrin.afandi@gmail.com (Y.A.); h.suheri@live.com (H.S.) \\ 2 Soil and Earth Sciences Group, Institute of Agriculture and Environment, Massey University, \\ Private Bag 11-222, Palmerston North 4474, New Zealand \\ 3 Medical Faculty, University of Mataram, Jl. Pendidikan No. 37, Mataram 83127, Indonesia; \\ ekawantimuhaimin@gmail.com \\ * Correspondence: c.w.n.anderson@massey.ac.nz; Tel.: +64-6-356-9099
}

Academic Editor: W. Scott Dunbar

Received: 28 June 2016; Accepted: 9 August 2016; Published: 15 August 2016

\begin{abstract}
Mine tailings are generally disposed of by artisanal and small scale gold miners in poorly constructed containment areas and this leads to environmental risk. Gold phytomining could be a possible option for tailings management at artisanal and small-scale gold mining (ASGM) locations where plants accumulate residual gold in their above ground biomass. The value of metal recovered from plants could offset some of the costs of environmental management. Getting gold into plants has been repeatedly demonstrated by many research groups; however, a simple working technology to get gold out of plants is less well described. A field experiment to assess the relevance of the technology to artisanal miners was conducted in Central Lombok, Indonesia between April and June 2015. Tobacco was planted in cyanidation tailings $(1 \mathrm{mg} / \mathrm{kg}$ gold) and grown for 2.5 months before the entire plot area was irrigated with $\mathrm{NaCN}$ to induce metal uptake. Biomass was then harvested (100 kg), air dried, and ashed by miners in equipment currently used to ash activated carbon at the end of a cyanide leach circuit. Borax and silver as a collector metal were added to the tobacco ash and smelted at high temperature to extract metals from the ash. The mass of the final bullion ( $39 \mathrm{~g}$ ) was greater than the mass of silver used as a collector ( $31 \mathrm{~g})$, indicating recovery of metals from the biomass through the smelt process. The gold yield of this trial was low $(1.2 \mathrm{mg} / \mathrm{kg}$ dry weight biomass concentration), indicating that considerable work must still be done to optimise valuable metal recovery by plants at the field scale. However, the described method to process the biomass was technically feasible, and represents a valid technique that artisanal and small-scale gold miners are willing to adopt if the economic case is good.
\end{abstract}

Keywords: cyanide tailings; plants; gold; artisanal and small scale gold mining; smelting

\section{Introduction}

While many large-scale gold mining operations have struggled with economic viability as the gold price has dropped from historic highs in 2011, the number of artisanal and small-scale gold mining (ASGM) around the world has continued to increase. This mining technique is defined as informal mining that may be legal or illegal, and which uses basic methods to extract gold from ore [1]. Worldwide, approximately 16 million gold miners produce between 380 and $450 \mathrm{t}$ of metal each year from at least 70 countries [2]. The informal nature of mining leaves miners exposed to exploitation; and while ASGM is not necessarily a criminal activity, mining in Latin America (for example) has in 
many locations become controlled by criminal groups who have turned to gold mining due to the potential for high profit margins [3].

Artisanal and small-scale gold mining is an important livelihood in many low- and middle-income countries where poverty is widespread. While direct employment in mining is important, a further six to ten jobs are thought to be created in the local economy by each miner, and this represents a significant livelihood for often poor communities [4,5]. However, mining is generally conducted with little or no attention to environmental management. Pollution of soil and water with cyanide, mercury and other trace elements is common, depending on the mining flow sheet employed. Mine tailings, the final waste product of mining, are generally disposed of in poorly constructed containment areas and this leads to transfer of contaminants to food and water, exposure pathways, and unacceptable environmental risk. Veiga stated that 'practical concepts of tailings management are badly needed in most of the artisanal and small-scale mining regions' [6]; however, very little scientific attention has been placed on this subject.

Worldwide commentary is unanimous in the message that the legal status of miners and mining must be recognised if social and environmental conditions of the sector are to be improved. A legal status for miners brings about resources to protect, remediate and rehabilitate the consequences of mining, and establishes a level of accountability for these consequences [3]. This is particularly important for the larger artisanal operations that may process as much as 5000 metric tonnes of ore per day [7]. Artisanal does not, therefore, refer to the scale of an operation. Artisanal instead refers to the rudimentary and informal nature of techniques used for mining [8].

Krisnayanti et al. proposed that gold phytoextraction could be a possible option for tailings management at ASGM locations [9]. This idea was based on an earlier field demonstration of gold phytoextraction technology at a mine site in Brazil, where corn and mustard plants were induced to accumulate gold from low-grade gold ore $(0.6 \mathrm{~g} / \mathrm{t})$ using a one-time application of cyanide solution to the soil [10]. The principle here is to use plants to accumulate soluble gold in their above-ground biomass, not to leach the gold into underlying rock. This concept has been described elsewhere as a 'Phyto leach pad' [11]. Any revenue recovered from harvested plants through processing the biomass for gold could be used to offset the cost of more effective tailings design and management.

Getting gold into plants has been repeatedly demonstrated by many research groups [12]. However, a working technology to get gold out of plants is less well described. In a recent review of the status of phytomining, Robinson et al. described how working models for the construction of infrastructure to process metal-rich biomass to yield saleable metal are lacking [13]. Gold phytomining at ASGM locations will depend on simple technology to recover the final metal product. Models based on acid leaching and solvent extraction of a clean ash (e.g., [12]) are unlikely to be technically viable. Gold phytomining for ASGM must utilise existing viable and accepted technologies. The borax method to smelt gold concentrates is one option.

This paper describes the results of a field demonstration of gold phytomining at an ASGM location on the island of Lombok, West Nusa Tenggara Province, Indonesia. This work was conducted to assess the ability of miners to apply phytomining to tailings, and to carry out a complete operation from planting to final processing of the biomass. This work is a key step towards the eventual uptake of phytomining as a technology to manage the long-term environmental liability of ASGM mine waste.

\section{ASGM in Indonesia and Research Location}

Historical records indicate that artisanal and small scale gold mining has been practiced in Indonesia for hundreds of years, from at least the 17th century, although the scale of operation increased dramatically from about 2000 [14]; since 2001, historical mining in Sulawesi, Kalimantan, Java and Sumatra has moved to new provinces in east Indonesia, specifically to West Nusa Tenggara. Mining through much of this period has been totally unregulated with widespread recorded damage on the environment throughout the archipelago. However, the benefits of mining on local communities are similarly recorded: increased employment; reduced criminality, increased community income, 
alternative livelihood during the dry season, increased participation in schooling, increased purchasing power of communities, reduced conflict within communities and reduced temptation for people to migrate overseas for work [15]. In response to the current situation, the Government of Indonesia is working towards a stronger legal framework for artisanal mining. The current Mineral and Coal Law No. 4/2009 introduced the concept of People Mining, and grants the power to local-level government to issue mining permits where miners operate within designated people mining areas. This is a major step towards formalisation of the artisanal mining sector in Indonesia. Progress to implement this new legislation is happening contemporaneously with the government's National Action Plan (NAP) to eliminate mercury from ASGM as required under the terms of the Minamata Convention on Mercury.

The first record of ASGM West Nusa Tenggara was on the island of Lombok and dates to 2009 following exploration of the south west part of the island for gold mineralisation [9]. While gold reserves proved unfavourable for large-scale mining, grades were sufficient to encourage an influx of artisanal and small-scale miners from other parts of Indonesia, and mining soon commenced. Krisnayanti et al. presented an assessment of environmental impact across the Sekotong mining district due to ASGM [9], while Krisnayanti and Anderson analysed the gold value-chain in Lombok and estimated that more than 15,000 people were involved with ASGM in Sekotong producing in excess of 50,000 tonnes of tailings a year [16]. None of these tailings are contained within managed long-term tailings facilities. Mining has subsequently moved westward as far as the district of Bima on the adjacent island of Sumbawa.

The district of Pringgarata, in Central Lombok Regency was selected as a location to demonstrate phytomining on ASGM tailings in 2015 (Figure 1). No hard-rock mining is practiced in Pringgarata District. Instead ore is brought from mining areas for processing due to the availability of flat land, water and a large workforce. Pringgarata District is well known as a rice producer, and the area is supported by extensive infrastructure for irrigation and drainage. The potential impacts of ASGM in this area are therefore of more concern here than in other areas where there is less direct competition for natural resources.

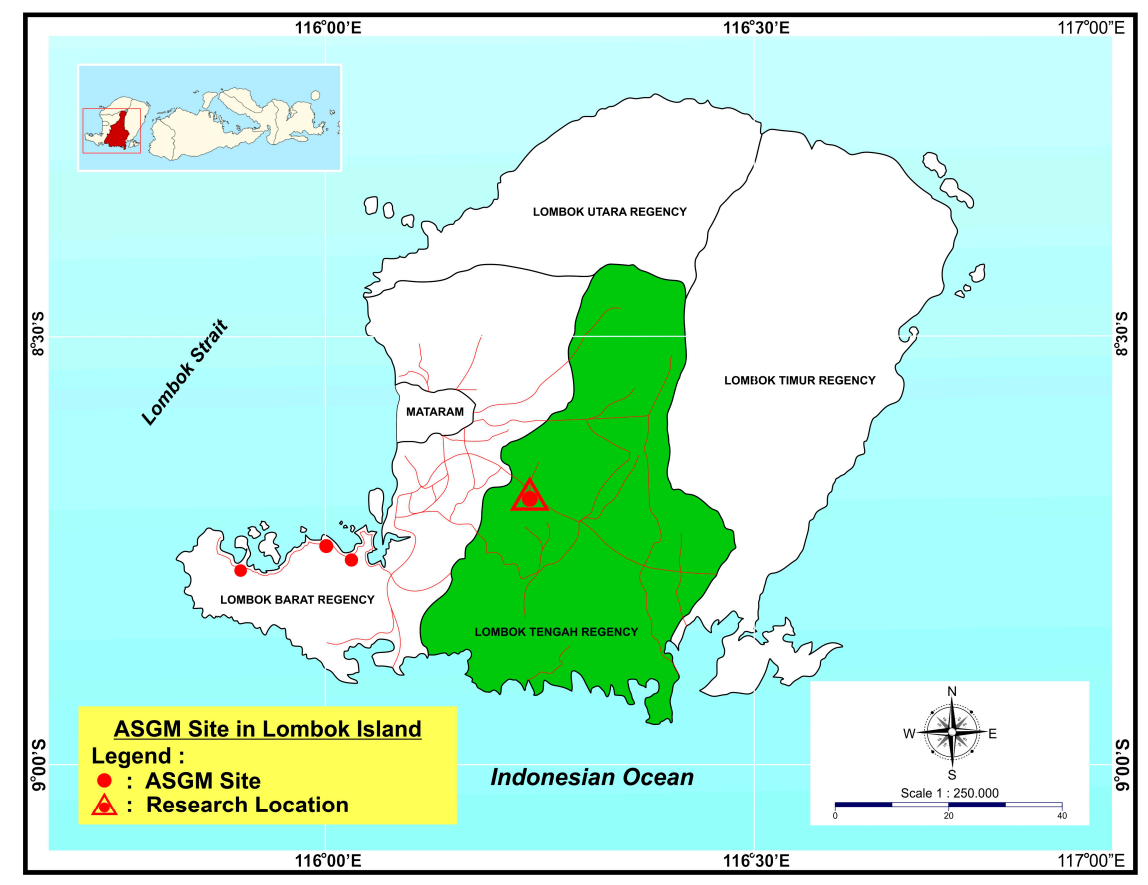

Figure 1. Location of the phytomining demonstration trial in Pringgarata District, Central Lombok Regency, West Nusa Tenggara, Indonesia. 
ASGM in Pringgarata District began in 2010. Whole ore amalgamation (gelondong) and cyanide leaching of amalgamation tailings (tong) is practiced throughout Pringgarata. Mine waste is regularly discharged into irrigation and drainage canals, and there is concern that contaminants in the waste can cause environment damage to vegetation (specifically rice), water quality, and to aquaculture. The environmental impact of discharged contaminants is not necessarily limited to Pringgarata. The drainage system in Central Lombok connects to both the West Lombok Regency and to Mataram City. The ASGM workforce in Pringgarata is supported by migrant workers from Kalimantan who are experienced with ASGM techniques. The level of technical capability for ASGM processing in Pringgarata is therefore relatively high. Many of the migrants may have actually been born in Central Lombok, but left to pursue jobs outside of the island, and have now returned to their homeland to seek gold.

\section{Field Trial Establishment and Operation}

A tailings area of $41 \mathrm{~m}$ by $13 \mathrm{~m}$ was delineated and established as the test plot for the phytomining trial. Replicate core samples (five) were collected to $30 \mathrm{~cm}$ depth using a corer with internal diameter of $2 \mathrm{~cm}$, for baseline nutrient and metal concentration (0-15 and 15-30 cm depth analysed separately). Existing vegetation across the site was cleared by hand and the tailings surface tilled using a hoe. A basal application of Red Phonska fertiliser was applied at a rate of $200 \mathrm{~kg} / \mathrm{ha}(15 \% \mathrm{~N}, 15 \% \mathrm{P}, 15 \% \mathrm{~K}$, $15 \% \mathrm{~S})$.

The local Kasturi variety of tobacco was used in this trial and hand planted at a $20 \mathrm{~cm}$ by $20 \mathrm{~cm}$ spacing at the end of the 2015 rainy season (from April to June). Tobacco is a crop that is well suited to the tropical Lombok environment and has shown great propensity in past research to uptake metals [17]. The local variety was used in preference to commercial varieties due to the experience of farmers and miners to growing this variety. Familiarity with a crop is a key issue for consideration in the use of an innovation such as phytomining in new locations.

Tobacco was grown for 2.5 months with no watering or pest control employed (Figure 2a). Weeding was conducted by hand every three weeks to manage the growth of weed grass species across the plot area.

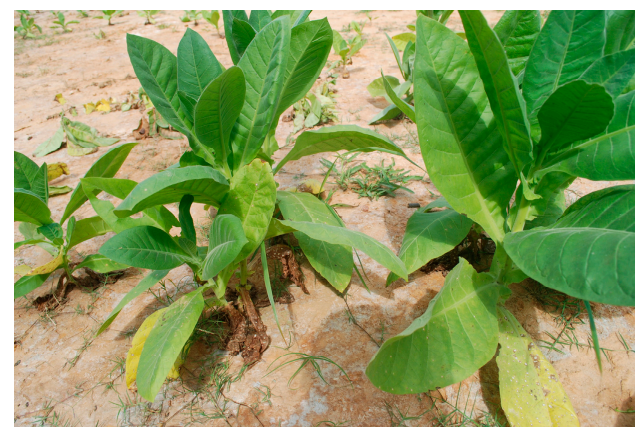

(a)

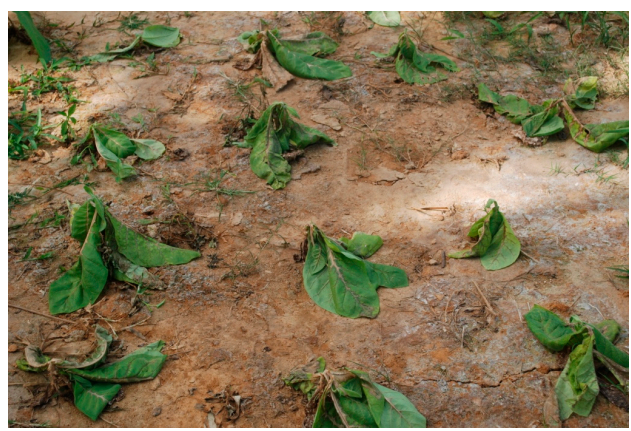

(b)

Figure 2. Tobacco plants before (a) and after (b) irrigation of the tailings surface with $\mathrm{NaCN}$.

After 2.5 months, the entire plot area was irrigated with a $2.11 \mathrm{~g} \mathrm{CN} / \mathrm{L}$ solution of $\mathrm{NaCN}$ to achieve a soil treatment dose of $0.05 \mathrm{~g} \mathrm{CN}$ per $\mathrm{kg}$ of tailings. Sodium cyanide was dissolved in water ( $\mathrm{pH} 7.5$; no addition of lime or calcium hydroxide to stabilise $\mathrm{pH}$ ) and hand irrigated onto tobacco plants during the hottest part of the day when evapotranspirative demand was at its peak. The underpinning principle of phytomining is that plants will accumulate a soluble gold-cyanide complex as a function of transpiration. Uptake is therefore proportional to the water demand and use efficiency of a crop [18]. The aim of phytomining is to have plants accumulate the soluble gold-cyanide complex, not leach this through the soil profile. 
Three days after treatment, tobacco leaves were chlorotic (Figure $2 b$ ) and were harvested. Approximately $100 \mathrm{~kg}$ of fresh biomass was collected. This reduced to $20 \mathrm{~kg}$ of dry weight biomass after several weeks drying in the sun.

Tailings samples collected from across the field plot prior to planting, and five bulk subsamples of harvested biomass (50 $\mathrm{g}$ a sample) were sent to the Soil and Earth Sciences Laboratory, Massey University for heavy metal analysis. Mercury analysis of the tailings and quantification of the soil nutrient properties of the tailings were performed at the University of Mataram on Lombok Island.

\section{Soil and Plant Analysis}

The gold concentration in the tailings and harvested biomass was determined following the methodology described by Anderson et al. [10]. Triplicate sub-samples of each tailings sample ( $1 \mathrm{~g})$ were digested in aqua regia $(10 \mathrm{~mL})$ using a digestion block, then made to $50 \mathrm{~mL}$ with deionised water. Bulk samples of dry biomass were ground using a Cyclotec 1093 Sample Mill, before replicate subsamples of ground biomass $(100 \mathrm{mg})$ were accurately weighed into borosilicate test tubes and ashed at $500{ }^{\circ} \mathrm{C}$ for $20 \mathrm{~h}$. The ash was digested in aqua regia $(2.5 \mathrm{~mL})$ on a water bath and the digest solutions made to a final volume of $10 \mathrm{~mL}$ with deionised water.

For gold analysis, aliquots $(5 \mathrm{~mL})$ of the digest solutions were extracted into methyl isobutyl ketone (MIBK) before quantification of the gold concentration in the organic phase by Graphite Furnace Atomic Absorption Spectroscopy (GFAAS, Perkin Elmer AAnalyst 600, Waltham, MA, USA). Calibration standards were prepared from Spectrosol $1000 \mathrm{mg} / \mathrm{L}$ gold solution, and reagent blanks were carried through the analytical procedure. Quality Control was assured through the use of an internal high-gold biomass samples [10]. Analytical measures differed by less than $10 \%$ of the expected value.

The silver and copper concentration in both tailings and biomass digest solutions was determined by Microwave Plasma Atomic Emission Spectroscopy (MP-AES, Agilent Technologies 4200, Santa Clara, CA, USA). The Hg concentration in the digest solution was quantified using Cold Vapour Atomic Absorption Spectroscopy (CVAAS; Huaguang model F732-S, Shanghai, China). Calibration standards were prepared from Spectrosol $1000 \mathrm{mg} / \mathrm{L}$ standard solutions, and reagent blanks were carried through the analytical procedure. Quality Control was assured through the use of a certified standard reference material (PTM-1a). Analytical measures differed by less than $10 \%$ of the expected value.

Tailings samples were analysed for soil nutrient properties at the University of Mataram, Indonesia according the methods described by Blakemore et al. to assess the extent to which a lack of fertility in cyanide tailings may affect plant growth [19]. Organic carbon was measured using the Walkley and Black method; total nitrogen by Kjedalh digest; and the exchangeable cations $\mathrm{K}, \mathrm{Ca}, \mathrm{Mg}$ and a determined through neutral ammonium acetate extraction. Available phosphate (Olsen P) was extracted in $0.5 \mathrm{M}$ sodium bicarbonate at a soil:solution ratio of 1:20. Available sulphate was extracted with $0.1 \mathrm{M}$ potassium phosphate at a soil:solution ratio of 1:5. Phosphate and sulphate concentrations in the extract solution were determined colorimetrically.

The concentration of nutrient elements and metal in the tailings is summarised in Table 1. The tailings showed elevated $\mathrm{pH}$ which is a consequence of lime added to ground ore during cyanide leaching. The carbon and nitrogen content of the tailings was low, and associated with this, cation exchange capacity (CEC; calculated as a function of the sum of exchangeable base cations) was also low; $10.8 \mathrm{me} \%$ and $12.28 \mathrm{me} \%$ for the $0-30$ and $>30 \mathrm{~cm}$ soil depth respectively. For comparison, the CEC) of a good agricultural soil is about $30 \mathrm{me} \%$ [20]. The gold concentration of the tailings is in agreement with a previous analysis of cyanidation tailings in Lombok [9], while the mercury concentration is considerably lower, likely due to a reduction in mercury use in Lombok since 2014 as miners move to cyanidation in preference to amalgamation. The mercury concentration in tailings is, however, in excess of the maximum allowable concentration of mercury in soil set by the Government of Indonesia $(20 \mathrm{mg} / \mathrm{kg}$ ) and therefore the tailings can be considered contaminated for agricultural land-use. 
The gold, copper and silver concentration in the harvested biomass is summarised in Table 2. The concentration of gold and copper in plants was low relative to values previously reported for phytomining field demonstration (e.g., [10]) and is approximately equivalent to a bioaccumulation factor of 1 (concentration of metal in plants/concentration of metal in soil). The gold concentration in plants was considerably lower that the target of $100 \mathrm{mg}$ gold $/ \mathrm{kg}$ dry biomass which has been set in previous literature [10]. To achieve this target, the bioaccumulation factor needs to be about 100 times greater on this area of tailings, or lower if tailings with a higher concentration for gold can be found. A published model for gold phytomining suggests that a gold concentration of approximately $50 \mathrm{mg} / \mathrm{kg}$ can be expected from 'soil' with a gold concentration of $1 \mathrm{mg} / \mathrm{kg}$. There is therefore considerable opportunity for optimisation of treatment of the plants to promote increased gold uptake in future studies. Past phytomining studies have not reported the silver content of plants. The bioaccumulation factor for silver was 3 , leading to a high concentration of silver in plants relative to what is normally expected (less than $0.1 \mathrm{mg} / \mathrm{kg}$ ). Silver is a toxic metal, and uptake of silver after cyanide treatment of plants has been previously attributed to necrosis of plants and a shutdown of evapotranspiration and metal uptake [21]. The elevated silver concentration in the biomass of this study may, in part, explain the low gold concentration.

Table 1. Physiochemical properties of the cyanidation tailings used as the substrate for the phytomining demonstration trial. Values and mean and standard deviation of five replicates.

\begin{tabular}{|c|c|c|c|c|c|}
\hline \multirow{3}{*}{ Parameter } & \multirow{3}{*}{ Unit } & \multirow{2}{*}{\multicolumn{2}{|c|}{$\begin{array}{l}\text { Depth Interval } \\
0-15 \mathrm{~cm}(n=5)\end{array}$}} & \multirow{2}{*}{\multicolumn{2}{|c|}{$\begin{array}{l}\text { Depth Interval } \\
>15 \mathrm{~cm}(n=5)\end{array}$}} \\
\hline & & & & & \\
\hline & & Mean & SD & Mean & SD \\
\hline $\mathrm{pH}$ & & 8.06 & 0.26 & 8.02 & 0.04 \\
\hline Org-C & $\%$ & 0.28 & 0.08 & 0.26 & 0.05 \\
\hline Total N & $\%$ & 0.01 & 0.01 & 0.02 & 0.00 \\
\hline Olsen P & $\mathrm{mg} / \mathrm{kg}$ & 27.6 & 2.7 & 34.7 & 3.3 \\
\hline Exchangeable K & $\mathrm{me} \%$ & 0.33 & 0.08 & 0.38 & 0.13 \\
\hline Exchangeable $\mathrm{Ca}$ & $\mathrm{me} \%$ & 9.47 & 1.83 & 10.70 & 1.50 \\
\hline Exchangeable Mg & $\mathrm{me} \%$ & 0.58 & 0.17 & 0.64 & 0.24 \\
\hline Exchangeable $\mathrm{Na}$ & $\mathrm{me} \%$ & 0.42 & 0.18 & 0.56 & 0.27 \\
\hline Available S & $\mathrm{mg} / \mathrm{kg}$ & 227 & 97 & 311 & 228 \\
\hline $\mathrm{Hg}$ & $\mathrm{mg} / \mathrm{kg}$ & 83.8 & 55.7 & 86.9 & 47.8 \\
\hline $\mathrm{Au}$ & $\mathrm{mg} / \mathrm{kg}$ & 1.03 & 0.28 & 0.87 & 0.23 \\
\hline $\mathrm{Cu}$ & $\mathrm{mg} / \mathrm{kg}$ & 53.6 & 11.3 & 53.1 & 10.4 \\
\hline $\mathrm{Ag}$ & $\mathrm{mg} / \mathrm{kg}$ & 18.2 & 3.74 & 17.5 & 3.32 \\
\hline
\end{tabular}

Table 2 also presents the calculated metal content of the harvested biomass. This is the metal load of the plants that was targeted for recovery during the processing of the biomass that followed harvest.

Table 2. Metal concentration in dry biomass and the calculated metal content ( $\mathrm{g}$ ) in the $20 \mathrm{~kg}$ of harvested dry biomass. Concentration values are the mean and standard deviation of replicate analysis of the five bulk samples received in New Zealand $(n=5)$.

\begin{tabular}{cccc}
\hline $\mathbf{m g} / \mathbf{k g}$ & Mean & SD & Metal Content in 20 kg Biomass (g) \\
\hline $\mathrm{Au}$ & 1.20 & 0.25 & 0.024 \\
$\mathrm{Ag}$ & 54.3 & 31.9 & 1.086 \\
$\mathrm{Cu}$ & 39.7 & 9.78 & 0.793 \\
\hline
\end{tabular}




\section{Processing the Dry Biomass}

Hydrometallurgical flow-sheets to recover gold (or other metals) from ore are generally not optimised to material that has a high concentration of organic matter, and are therefore poorly suited to the processing of biomass. This has been a major impediment to the development of an economically viable biomass processing system to support the commercial roll-out of phytomining [11]. The first step in proposed flow-sheets for biomass processing is to reduce the biomass to ash [13,22], and this first step was employed in the current study (Figure 3). Burning of carbon is a common practice at ASGM locations in Indonesia where miners burn the activated carbon recovered from the cyanidation process (CIL). Dry biomass was treated in the same way as activated carbon, and ashed in a clay pot with forced air as an additional oxidant (Table 3). The final mass of ash was $5.54 \mathrm{~kg}$ from the $20 \mathrm{~kg}$ of dry biomass. This is a mass reduction by a factor of 4 . Complete burning of all organic material in the biomass should yield a mass reduction by a factor of greater than 10 . Therefore, ashing was incomplete.

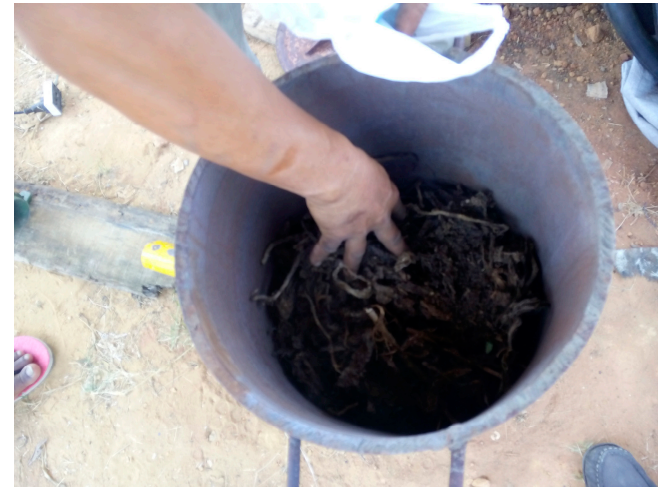

(a)

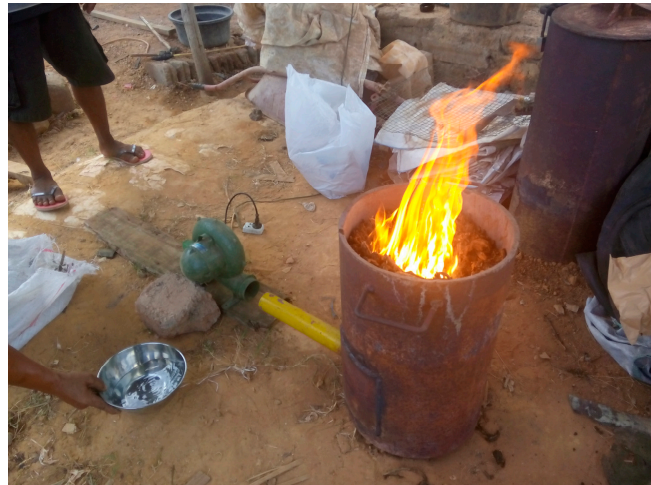

(b)

Figure 3. Loading the sun dried biomass into a steel drum (a) and burning the biomass to generate a plant ash (b).

Table 3. Detail of the smelting process used to recover metal from the harvested biomass.

\begin{tabular}{|c|c|c|c|c|c|c|c|}
\hline \multirow[b]{2}{*}{ Run } & \multirow{2}{*}{$\begin{array}{c}\text { Tobacco } \\
\text { Biomass } \\
(\mathrm{kg})\end{array}$} & \multicolumn{3}{|c|}{ Ashing } & \multicolumn{3}{|c|}{ Smelting } \\
\hline & & $\begin{array}{l}\text { Time } \\
(\min )\end{array}$ & $\begin{array}{l}\text { Temp. } \\
\left({ }^{\circ} \mathrm{C}\right)\end{array}$ & $\begin{array}{l}\text { Product } \\
\text { (kg) }\end{array}$ & $\begin{array}{c}\text { Borax Added } \\
(\mathrm{kg})\end{array}$ & $\begin{array}{l}\text { Time } \\
\text { (min) }\end{array}$ & $\begin{array}{l}\text { Temp. } \\
\left({ }^{\circ} \mathrm{C}\right)\end{array}$ \\
\hline 1 & 1.031 & 22.3 & 302 & 0.282 & 0.282 & 27.21 & $>1000$ \\
\hline $\begin{array}{c}2 a^{1} \\
2 b\end{array}$ & 4.510 & 35.15 & 314 & 1.276 & 1.276 & $\begin{array}{l}32.25 \\
34.24\end{array}$ & $\begin{array}{l}>1000 \\
>1000\end{array}$ \\
\hline
\end{tabular}

Note: $1.35 .15 \mathrm{~g}$ of ash produced from the second ash run was split into two equal portions for smelting due to capacity limitations of the clay smelting pot.

Further processing of the ash was based on the borax method which is currently used in the northern Philippines by more than 15,000 small-scale miners as a mercury-free alternative to gold processing and has been demonstrated throughout West Nusa Tenggara Province [23]. The borax method is a smelt technique that can be economically used to recover gold from concentrates, and could be a viable method to further process the gold (and other precious metals) present in biomass ash. Borax was added to the tobacco ash (1:1 ratio) and smelted at high temperature for approximately $30 \mathrm{~min}$ (Table 3) using an oxy-acetylene torch and compressed air (Figure 4). The product of this smelt was $1.23 \mathrm{~kg}$ of slag. 


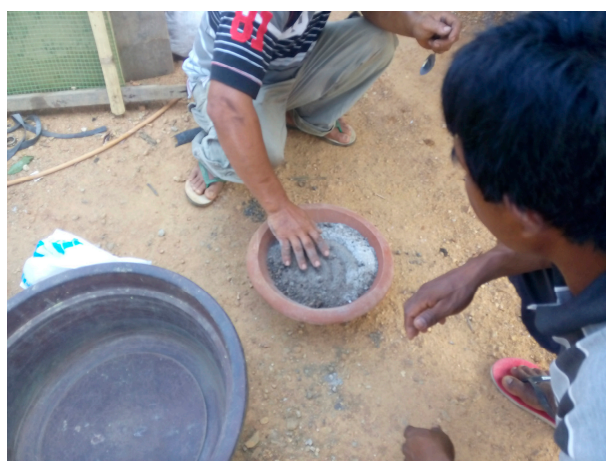

(a)

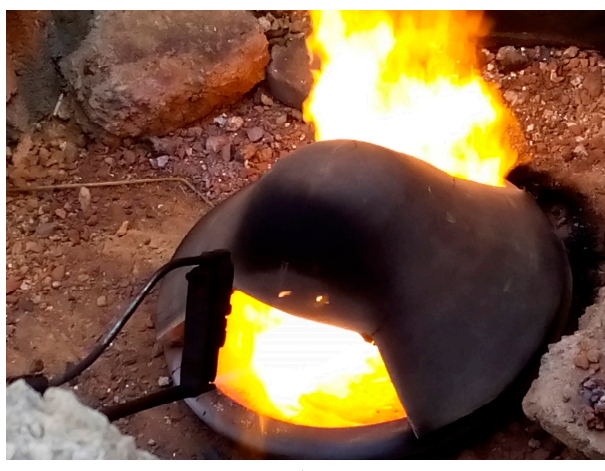

(b)

Figure 4. Mixture of plant ash and borax (a) and smelting the tobacco ash (b).

There was no visible separation of metal product within the smelt product (slag). To further process the slag, silver (99\%), purchased from a gold shop in the city of Mataram, was used as a collector metal during a second smelt. The $1.23 \mathrm{~kg}$ of slag was crushed by hand and then mixed with a further $250 \mathrm{~g}$ of borax. Silver pieces (30.97 g) were then spread over the surface of the slag/borax mix, the clay pot covered, and a second smelt run for $1.5 \mathrm{~h}$ (temperature greater than $1000{ }^{\circ} \mathrm{C}$ ) using an oxy-acetylene torch and compressed air (Figure 5). The smelt finished when the slag had completely melted and the silver had formed a single piece of visible bullion. The slag was then cooled for 2 min and poured on a flat surface and the silver recovered $(38.74 \mathrm{~g})$.

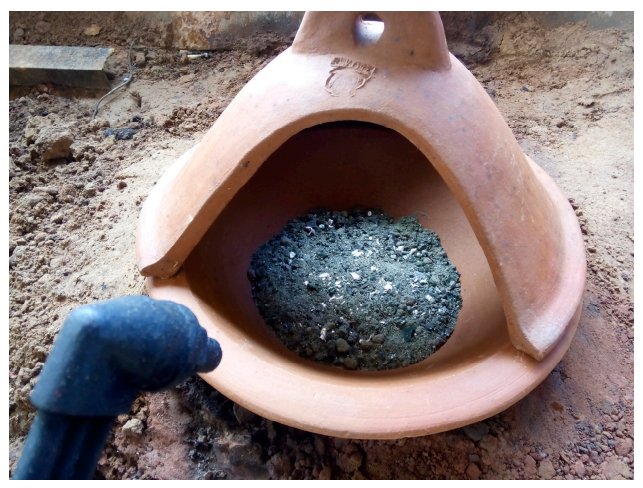

(a)

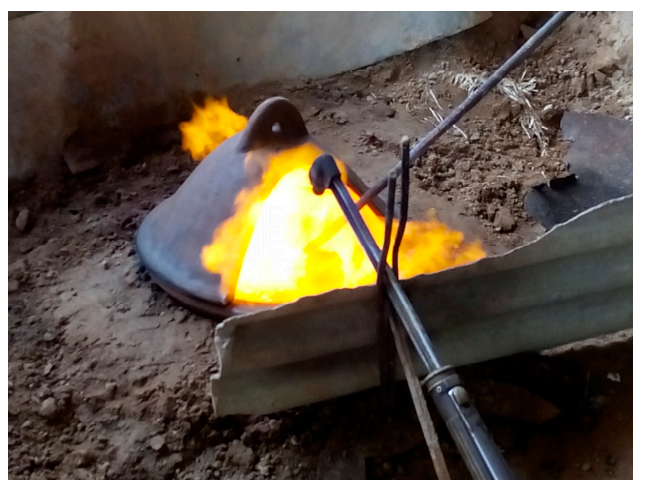

(b)

Figure 5. Final extraction process using silver as a collector metal before (a) and during smelting (b).

A sample of the silver used as a collector and the silver bullion produced by the smelt was analysed using XRF (Rigaku NEX CG, Cartesian geometry energy dispersive X-ray fluorescence spectrometer) at the Agency for the Assessment and Implementation of Technology (BPPT), Serpong, Jakarta. Table 4 presents the metal concentration in the silver and the bullion, and the calculated mass of analysed metal in the smelt product. The mass of bullion recovered from the smelt was greater than the initial mass of silver added. A mass balance closure from Table 4 is not possible due to the semi-quantitative nature of the XRF technique employed, however the data in Table 4 indicate that the silver content of the biomass (1.086 g; Table 2) has been recovered in the silver bullion due to the appreciable increase in calculated silver mass for the smelt product. The copper content of the bullion as estimated by the XRF results is lower than the calculated from the dry biomass (0.793 g; Table 2) and this indicates relatively poor recovery of copper into silver during the smelt. No conclusion can be made on the gold content of the bullion due to the very low XRF value, and the low content of gold in the $20 \mathrm{~kg}$ of biomass. We believe that appreciable iron content of the bullion was collected from the biomass during the smelting process. 
Table 4. Metal concentration in the silver and bullion determined by XRF and the calculated mass of metal in the final smelt product. Significant figures used for metal concentration based on the XRF limit of detection for each metal.

\begin{tabular}{cccc}
\hline \multirow{2}{*}{ Metal } & Concentration in Ag Collector (\%) & \multicolumn{2}{c}{ Bullion Produced During Smelt } \\
\cline { 3 - 4 } & & Concentration (\%) & Mass (g) \\
\hline $\mathrm{Fe}$ & 1.01 & 6.15 & 2.383 \\
$\mathrm{Cu}$ & 0.079 & 0.629 & 0.244 \\
$\mathrm{Zn}$ & - & 0.0469 & 0.018 \\
$\mathrm{Ag}$ & 98.90 & 93.1 & 36.07 \\
$\mathrm{Au}$ & 0.0455 & 0.0244 & 0.009 \\
$\mathrm{~Pb}$ & - & 0.0234 & 0.009 \\
$\mathrm{Sum}$ & 100 & 99.974 & - \\
\hline
\end{tabular}

\section{The Response of the Miners to Phytomining and Potential for Practical Use at ASGM Locations}

The gold concentration in the harvested biomass, and therefore the total gold recovery from the trial plot, was considerably lower than the target for gold phytomining. However, the trial was able to demonstrate to miners the complete phytomining sequence, from site preparation to final recovery of a metal product. The increased mass of silver recovered from the final smelt, relative to the mass of silver added, and the increased silver concentration of this bullion, suggests that the borax smelting technique utilising silver as a collector successfully captured the precious metals within the biomass. This process was conducted without mercury on tailings land that is currently not subject to any environmental management.

There is good opportunity to improve the phytomining process to increase the concentration of metals in the biomass. The volume of cyanide solution can be optimised so that the root zone of the crop is flooded with soluble gold, leading to an increased concentration of gold in plants. Alternatively, tailings with a higher concentration of gold can be targeted; ASGM tailings with a gold concentration as high as $6 \mathrm{mg} / \mathrm{kg}$ can be found in some parts of Indonesia [24]. The gold concentration in plants is a function of the gold concentration in soil, and the extent to which this gold can be made soluble in the root zone of plants. The greater the concentration of gold in soil, the greater the concentration that can be induced into plants. A mean gold concentration in excess of $100 \mathrm{mg} / \mathrm{kg}$ has been reported for a gold concentration in soil as low as $2 \mathrm{mg} / \mathrm{kg}$ where treatment is optimised for plant uptake [10,21].

This work has been a first demonstration of phytomining to an ASGM community. Throughout the trial both the miners and community remained sceptical of the idea. Phytomining is a new concept that is 'beyond their common way of thinking'. ASGM miners are slow to embrace new ideas that they do not understand; they look for immediate payback on their efforts and miners would need a clear economic incentive to wait 3-4 months for a crop of metal to develop. Further demonstrations within mining communities will be necessary before the idea sees greater acceptance. These demonstrations, while not only optimising the technology and process, should consider the economic case for phytomining. The trial described in this paper has not sought to quantify the costs associated with the operation (crop planting and maintenance, treatment with cyanide, harvesting, and processing). Therefore, the possible margin that may be accrued through the system has not considered. More detailed economic analysis will be the focus of future studies in West Nusa Tenggara Province that build upon these initial findings.

However, the applied value of phytomining may not be an economic profit. Instead the economic argument for phytomining may be as a source of revenue that can pay (in part or in full) for the sustainable management of ASGM tailings. Miners discharge tailings into the environment as it has no residual value and therefore it is disposed of in the simplest way. They have no technology that can exploit the residual gold content, and there is no economic penalty associated with their actions. Phytomining could be used as a system to recover some of the cost of investment in the construction 
of tailings storage facilities at ASGM locations [9]. A designed tailings dam could prevent the release of contamination into agricultural land and could be coupled to an engineered bioreactor (constructed wetland) to treat leachate discharging from the tailings dam [25]. Several years of phytomining could recover some of the cost of building and managing the tailings facility, rehabilitating the tailings for subsequent planting in forestry. This would mitigate the risk apparent today of tailings dams drying up, naturally revegetating with grass, and become grazing land for cattle. The extent to which these cattle are exposed to and biomagnifying contaminants in tailings such as mercury is currently unknown. A safer long-term plan for these areas would be forestry, where the community can harvest a valuable crop 20-30 years after planting. The economic logic behind this scenario must be explored through ongoing field demonstrations within an ASGM community.

Phytomining as described in this paper sense sits at the interface of mining and biotechnology and can be considered in this context as a mechanism for sustainable community-based agricultural development. Skills in sustainable nutrient management developed during a phytomining operation could be usefully applied to the production of food or other agricultural crops on clean land. The example in this study is tobacco, which remains a major cash crop in east Indonesia. It is imperative that tailings in ASGM areas is not used for food production, and care must be taken to ensure that crops grown on tailings are not released for human consumption. Agromining (a variant of phytomining) may therefore be a better term to describe the process where communities are provided with an alternative agricultural land-use option for degraded land where they farm for metals not for food crops [22]. The science and technology to increase the metal concentration in plants exists, and must be further demonstrated to miners and farmers in ASGM communities. The processing system proposed in this paper must also be further demonstrated, to allow for more complete assessment of the feasibility of phytomining or agromining for sustainable tailings management in ASGM areas. The economic case for phytomining will only become apparent when a saleable value can be put on the final product from a scaled-up phytomining operation.

Acknowledgments: The research was funded by the Ministry of Education of the Republic Indonesia through the International Research Collaboration and Scientific Publication scheme in 2015. The authors gratefully acknowledge the Centre for Mineral Resources Technology, Agency for the Assessment and Application of Technology (BPPT), Indonesia and the Blacksmith Institute, Indonesia for assistance in analyzing our samples.

Author Contributions: Baiq Dewi Krisnayanti, Christopher W.N. Anderson and S. Sukartono conceived and designed the experiments; Yusrin Afandi and Herman Suheri performed the experiments; Baiq Dewi Krisnayanti and Christopher W.N. Anderson analyzed the data; Ardiana Ekawanti contributed analysis tools; Baiq Dewi Krisnayanti and Christopher W.N. Anderson wrote the paper.

Conflicts of Interest: The authors declare no conflict of interest. The funding sponsors had no role in the design of the study; in the collection, analyses, or interpretation of data; in the writing of the manuscript, and in the decision to publish the results.

\section{References}

1. Veiga, M.M. Introducing New Technologies for Abatement of Global Mercury Pollution in Latin America; Centro de Tecnologia Mineral-CETEM: Rio de Janeiro, Brazil, 2007.

2. Seccatore, J.; Veiga, M.M.; Origliasso, C.; Marin, T.; De Tomi, G. An estimation of the artisanal small-scale production of gold in the world. Sci. Total Environ. 2014, 496, 662-667. [CrossRef] [PubMed]

3. Wagner, L. The Global Initiative against Transnational Organised Crime. Organised Crime and Illegally Mined Gold in Latin America, Geneva, Switzerland, 2016. Available online: http://globalinitiative.net/wp-content/ uploads/2016/03/TGIATOC-OC-and-Illegally-Mined-Gold-in-Latin-America-Report-1718-digital.pdf (accessed on 16 April 2016).

4. United Nations Environment Programme (UNEP). Summary of Supply, Trade and Demand Information on Mercury; UNEP: Geneva, Switzerland, 2006.

5. Rajee, M.; Obiri, S.; Green, A.; Long, R.; Cobbina, S.J.; Nartey, V.; Buck, D.; Antwi, E.; Basu, N. Integrated assessment of artisanal and small-scale gold mining in Ghana-Part 2: Natural Sciences Review. Int. J. Environ. Res. Public Health 2015, 12, 8971-9011. [CrossRef] [PubMed]

6. Veiga, M.M.; Nunes, D.; Klein, B.; Shandro, J.A.; Velasques, P.C.; Sousa, R.N. Mill leaching: A viable substitute for mercury amalgamation in the artisanal gold mining sector? J. Clean. Prod. 2009, 17, 1373-1381. [CrossRef] 
7. Veiga, M.M.; Angeloci-Santos, G.; Meech, J. Review of barriers to reduce mercury use in artisanal gold mining. Extr. Ind. Soc. 2014, 1, 351-361. [CrossRef]

8. Veiga, M.M.; Angeloci, G.A.; Niquen, W.; Seccatore, J. Reducing mercury pollution by training Peruvian artisanal gold miner. J. Clean. Prod. 2015, 94, 268-277. [CrossRef]

9. Krisnayanti, B.D.; Anderson, C.W.N.; Utomo, W.H.; Feng, X.; Handayanto, E.; Mudarisna, N.; Ikram, H.; Khususiah. Assessment of environmental mercury discharge at a four-ear-old artisanal gold mining area on Lombok Island, Indonesia. J. Environ. Monit. 2012, 14, 2598-2607. [CrossRef] [PubMed]

10. Anderson, C.; Moreno, F.; Meech, J. A field demonstration of gold phytoextraction technology. Min. Eng. 2005, 18, 385-392. [CrossRef]

11. Hunt, A.J.; Anderson, C.W.; Bruce, N.; Garcia, A.M.; Graedel, T.E.; Hodson, M.; Clark, J.H. Phytoextraction as a tool for green chemistry. Green Process. Synth. 2014, 3, 3-32. [CrossRef]

12. Wilson-Corral, V.; Anderson, C.W.N.; Rodriguez-Lopez, M. Gold phytomining: A review of the relevance of this technology to mineral extraction in the 21st century. J. Environ. Manag. 2012, 111, 249-257. [CrossRef] [PubMed]

13. Robinson, B.H.; Anderson, C.W.N.; Dickinson, N.M. Phytoextraction: Where's the action. J. Geochem. Explor. 2015, 151, 34-40. [CrossRef]

14. Aspinall, C. Small-Scale Mining in Indonesia; International Institute for Environment and Development: London, UK; The World Business Council for Sustainable Development: Geneva, Switzerland, 2001.

15. Prabangkara, Y.Y.; Haris, A.; Krisnayanti, D.; Anderson, C. The Indonesian Centre for Artisanal Mining (INCAM): Helping the nation to phase out of mercury from ASGM. In Proceedings of the 3rd International Workshop on Mineral Processing and Beneficiation, Harare, Zimbabwe, 11-14 September 2014.

16. Krisnayanti, B.D.; Anderson, C. Environmental Impact Assessment. Illegal/Informal Gold Mining in Lombok; Deutsche Gesellschaft für Internationale Zusammenarbeit (GIZ) GmbH (GIZ-RED): Jakarta, Indonesia, 2012.

17. Herzig, R.; Nehnevajova, E.; Pfistner, C.; Schwitzguebel, J.P.; Ricci, A.; Keller, C. Feasibility of labile Zn phytoextraction using enhanced tobacco and sunflower; results of five- and one-year field-scale experiments in Switzerland. Int. J. Phytoremed. 2014, 16, 735-754. [CrossRef] [PubMed]

18. Anderson, C. Biogeochemistry of gold: Accepted theories and new opportunities. In Trace and Ultratrace Elements in Plants and Soils (Advances in Ecological Science); Shtangeeva, I., Ed.; WIT Press: Southampton, UK, 2005; Volume 20, pp. 287-321.

19. Blakemore, L.C.; Searle, P.L.; Daly, B.K. Methods for Chemical Analysis of Soils; New Zealand Soil Bureau Scientific Report; Department of Scientific and Industrial Research (New Zealand): Palmerston North, New Zealand, 1987.

20. Hill Laboratories. Technical Notes: Cation Exchange Capacity and Base Saturation. Available online: http:/ / www.hill-laboratories.com/file/fileid/15507 (accessed on 15 June 2016).

21. Anderson, C.W.N.; Bhatti, S.M.; Gardea-Torresdey, J.; Parsons, J. In Vivo Effect of Copper and Silver on Synthesis of Gold Nanoparticles inside Living Plants. ACS Sustain. Chem. Eng. 2013, 1, 640-648. [CrossRef]

22. Van der Ent, A.; Baker, A.J.M.; Reeves, R.D.; Chaney, R.L.; Anderson, C.W.N.; Meech, J.A.; Mulligan, D.R. Agromining: Farming for Metals in the Future? Environ. Sci. Technol. 2015, 49, 4773-4780. [CrossRef] [PubMed]

23. Mitigating Mercury Emissions from Artisanal and Small-Scale Gold Mining in Indonesia. Available online: http://www.unep.org/chemicalsandwaste/Portals/9/Mercury/Final\%20Report\%20Narrative_ June2014.pdf (accessed on 17 April 2016).

24. Brotokusumu, W. Agency for the Assessment and Implementation of Technology, Jakarta, Indonesia; Masters of Environmental management Student, Massey University, Palmerston North, New Zealand. Personal communication, 2016.

25. Higgins, J.; Anderson, C. The use of engineered bioreactor systems for treating runoffs and leachates from artisanal gold mining operations. In Proceedings of the 2014 Sustainable Industrial Processing Summit \& Exhibition, Shechtman International Symposium, Cancun, Mexico, 29 June-4 July 2014.

(C) 2016 by the authors; licensee MDPI, Basel, Switzerland. This article is an open access article distributed under the terms and conditions of the Creative Commons Attribution (CC-BY) license (http://creativecommons.org/licenses/by/4.0/). 